\title{
EVALUATION OF MULTIPARAMETRIC ECHOGRAPHY IN DIAGNOSIS OF NONALCOHOLIC FATTY LIVER DISEASE IN TYPE 2 DIABETES MELLITUS
}

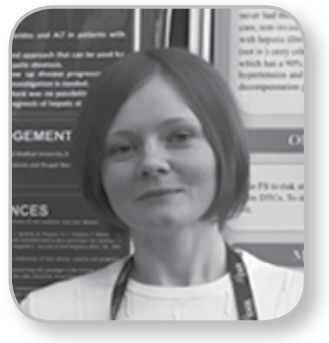

INTRODUCTION

Diabetes is one of the largest global health emergencies of the 21st century. According to the data of International Diabetes Federation (IDF) there are about 415 million people with diabetes and 318 million people with impaired glucose tolerance in the world. But there are also 193 million people with undiagnosed diabetes which are at high risk of developing chronic complications. IDF estimated that there would be 642 million people with diabetes by 2040 . The proportion of type 2 diabetes mellitus (T2DM) is $91 \%$ among all adults with diabetes [1]. It is known that non-alcoholic fatty liver disease (NAFLD) is one of the causes of disability and mortality in patients with T2DM. In Western countries NAFLD affects 17$46 \%$ of adults. The stages of NAFLD are steatosis, steatohepatitis and steatotic cirrhosis. Hepatocellular carcinoma is a complication of steatohepatitis even in the absence of cirrhosis [7]. Golden standard for diagnosis of NAFLD is liver biopsy, but this procedure can't be part of ordinary investigation in patients with T2DM because of such possible complications as postoperative pain, bleeding, bacteremia, biliary peritonitis, pneumothorax, hemothorax, subcutaneous emphysema, inflammation and mortality. Computer tomography (CT) of abdominal cavity and magnetic resonance tomography (MRI) are expensive procedures and can't be used for following patients up. That's why there is need for noninvasive and affordable methods for diagnosis of NAFLD in patients with T2DM. These methods must be used for differentiation of the stages of steatosis, quantitative evaluation of liver fat and liver stiffness measurement simultaneously. The recommendation of the European association for the study of the liver defines ultrasound (US) as the preferred first-line diagnostic procedure for imaging of NAFLD as US robustly diagnoses moderate and severe steatosis and provides additional hepatobiliary information [7]. But it is impossible to evaluate liver fat in hepatocytes quantitatively in US B-mode. For diagnosis of fatty liver in B-mode the criteria of Hamaguchi are used [11]. These criteria include hepatomegaly, attenuation of US in the liver in front posterior direction and vessel blurring. But the disadvantages of this method are differences in echogenicity of liver in healthy adults and operator-dependent interpretation of the results. Hepatorenal index and evaluation of histogram of liver echogenicity differentiate stages of steatosis [4]. Fibroscan (Echosens, France) is widely used in Europe because it includes simultaneous liver stiffness measurement with transient elastography and assessment of steatosis with steatometry and controlled attenuation parameter (CAP) respectively [12]. CAP as a method is presented by correlation of stage of attenuation in liver parenchyma in $\mathrm{dB} / \mathrm{m}$ with the stage of steatosis according to the morphological scale SAF/NAS [14]. But more data are needed to define the role of CAP [7]. Transient elastography of Fibroscan (Echosens, France) is limited for diagnosis of NAFLD in patients with T2DM and excessive weight and obesity because shear waves can't go through subcutaneous abdominal fat and there is no navigation of direction 
probe for fibroelastometry and steatometry. In 2014-2016 Ukrainian scientists proposed Soneus P7 (Ultrasign, Ukraine) device and invented the technology of quantitative evaluation of fat in hepatocytes in real time mode with attenuation coefficient measurement $(A C M)$ in $2 D$ dimensions of liver parenchyma in $\mathrm{dB} / \mathrm{cm}$ which is a part of multiparametric US of patient (Patent UA №2014111234).

The aim of this study is evaluation of multiparametric echography (MPE) in diagnosis of NAFLD in patients with T2DM.

\section{MATERIALS AND METHODS}

MPE is US method for investigation of abdominal cavity which includes simultaneous using of B-mode, dopplerography and dopplerometry, strain and shearwave elastography, elastometry, ACM, hepatorenal index on Soneus P7 (Ultrasign, Ukraine) device with convex transducer 1-6 MHz in right liver lobe. Our research consisted of two stages:

1. Testing the methodology of ACM for quantitative evaluation of steatosis.

2. Using the MPE for diagnosis and evaluation of NAFLD condition in patients with T2DM.

949 patients were investigated on Soneus P7 (Ultrasign, Ukraine) device with convex transducer 1-6 MHz for providing the first stage of research. The examination included evaluation of sound conduction in the liver parenchyma in frontal-posterior direction (attenuation of US in liver), contour of liver, frontalinferior edge and echotexture. Fatty liver disease was diagnosed according to Hamaguchi criteria in B-mode. The groups of patients with fatty liver disease included viral hepatitis (550), alcoholic fatty liver disease (210), autoimmune hepatitis (5) and patients with T2DM and exclusion of viral hepatitis (187). Control group consisted of 51 patients. Design of the study was crosssectional.

For evaluation of diagnostic value of ACM CT was used as reference method in 142 patients. Diagnostic group included 91 patients with steatosis and control group - 51 without fatty liver disease. Indication for conducting CT of abdominal cavity is focal lesions of liver with fatty liver disease according to US. At CT fatty liver was evaluated with Haunsfield units. The parameters of ACM of 49 patients with steatosis were compared with CAP on Fibroscan (Echosens, France).

At first according to the methodology of steatometry (SM) a window for acoustic access in B-mode must be selected. After that the selected depth of the region of interest (ROI) should not be closer than 1.5-
$2 \mathrm{~cm}$ to the liver capsule. For ACM US wave must be $4 \mathrm{~cm}$ deep. The width of the ROI was of $2-3 \mathrm{~cm}$ and it didn't include liver capsule, hilum, diaphragm and gall bladder. Depth of breath and compression of liver by transducer do not affect the ACM. It is recommended to make at least three ACM for getting the average results and SM of right liver lobe is preferred. The scale of the US attenuation (unit in $\mathrm{dB} / \mathrm{cm}$ ) is calibrated by a steatometry phantom $[5,6]$.

The second part of investigation included simultaneous US of organs of abdominal cavity on Soneus P7 (Ultrasign, Ukraine) device with convex transducer 1-6 MHz and included step by step investigation of organs of abdominal cavity in B-mode, dopplerography, dopplerometry, strain and shear wave elastography, elastometry, ACM (SM) in patients with NAFLD and T2DM.

Our research was conducted on the base of Kyiv clinical endocrinological center from 2015-2017. 111 patients with T2DM of both sexes ( 81 women and 24 men) at the age 18-79 were investigated. The inclusion criteria of the research were: presence of T2DM, age $\geq 18$ years, body mass index $\geq 25 \mathrm{~kg} / \mathrm{m}^{2}$, metformin as monotherapy or in combination with other hypoglycemic drugs.

The criteria of exclusion were: presence of antibodies to the viral hepatitis $B$ (HBsAg) and C (summary antibodies); alcohol abuse (more than $30 \mathrm{~g} /$ day of alcohol for men and $20 \mathrm{~g} /$ day of alcohol for women); drug abuse; pregnancy; mental illnesses; hazardous conditions of work (with toxic influence on the liver); parenteral nutrition; presence of hemochromatosis, autoimmune hepatitis, coeliac disease, WilsonKonovalov disease, hypopituitarism, decompensated hypothyroidism, syndrome of hypercorticism, lysosomal acid lipase deficiency (Wolman disease); type 1 diabetes mellitus; Crohn's disease.

Design of this study was cross-sectional. Six patients were excluded from the study because of presence of antibodies to hepatits B (HBsAg) (one person) and for hepatitis $C$ (summary antibodies) (five people).

The position of the liver was evaluated in B-mode (its position to the edge of costal arch and access of acoustic windows). Two lobes of the liver were investigated. Biometry of anterior-posterior size of these lobes was made during normal breathing of the patient. Contour (equal or not), anterior-inferior edge of the liver (sharp or round), echogenicity (normal, low or high) and echotexture (1-2 mm small; 3-4 mm middle; and $>5 \mathrm{~mm}$ big) were described. In B-mode according to Hamaguchi criteria sound conduction 
in the liver parenchyma or attenuation of US of the liver in anterior-posterior direction was evaluated. Hepatorenal index was measured in the same depth and ACM in liver parenchyma with US SM. Staging of steatosis according to the results of US SM was made according to the scale of US attenuation, proposed by Sasso et al. and validated morphological scale of fat infiltration NAS [14]:

1. SO is normal (proportion of hepatocytes with fat is $0-5 \%$ ): from 1.0 to $2.19 \mathrm{~dB} / \mathrm{cm}$;

2. S1 is mild steatosis (proportion of hepatocytes with fat is $5 \%>33 \%$ ): from 2.20 to $2.29 \mathrm{~dB} / \mathrm{cm}$;

3. S2 is moderate steatosis (proportion of hepatocytes with fat is $33 \%>66 \%$ ): from 2.30 to $2.90 \mathrm{~dB} / \mathrm{cm}$;

4. S3 is severe steatosis (proportion of hepatocytes with fat is more than $66 \%):>2.90 \mathrm{~dB} / \mathrm{cm}$.

US-dopplerography and dopplerometry of portal vein was conducted by the traditional methodology including metabolic activity of digestive system. Methodology of shear wave elastography and fibroelastometry/shear wave elasometry was performed according to the defined algorithm with inclusion of possible artefacts for evaluation of fibrosis stage and cirrhosis with Metavir scale (evaluation of liver stiffness measurement in $\mathrm{kPa}$ ) [3]:

1. No fibrosis (F0): $2.5-6 \mathrm{kPa}$

2. Mild fibrosis (F1): $6-7 \mathrm{kPa}$

3. Moderate fibrosis (F2): $7-9.5 \mathrm{kPa}$

4. Severe fibrosis (F3): $9.5-12.5 \mathrm{kPa}$

5. Cirrhosis (F4): 12.5 and more $\mathrm{kPa}$

\section{RESULTS}

For evaluation the diagnostic accuracy of ACM in patients with liver steatosis and in control group CT was used as a reference method. Liver steatosis was calculated in Haunsfield units. Stiffness of liver parenchyma in fatty liver disease is lowering (cutoff point for steatosis is 45 Haunsfield units and lower). In comparison of the data of patients with fatty liver disease with the data of $C T$ the negative medium correlation was revealed $(r=-0.622, p<0.001)$ (Fig. 1A) Coefficient of correlation in control group was $r=-$ 0.357 ( $p=0.004$ ) (Fig. 1B), which proves the significant correlation of ACM with the data of CT in patients with fatty liver disease and in control group. In patients with fatty liver disease low level of stiffness in liver parenchyma correlates with ACM negatively.

ROC-analysis was made for confirmation of the diagnostic accuracy of ACM. The parameters of CT data in patients with liver steatosis vs. controls were analyzed. Area under the ROC-curve of ACM for
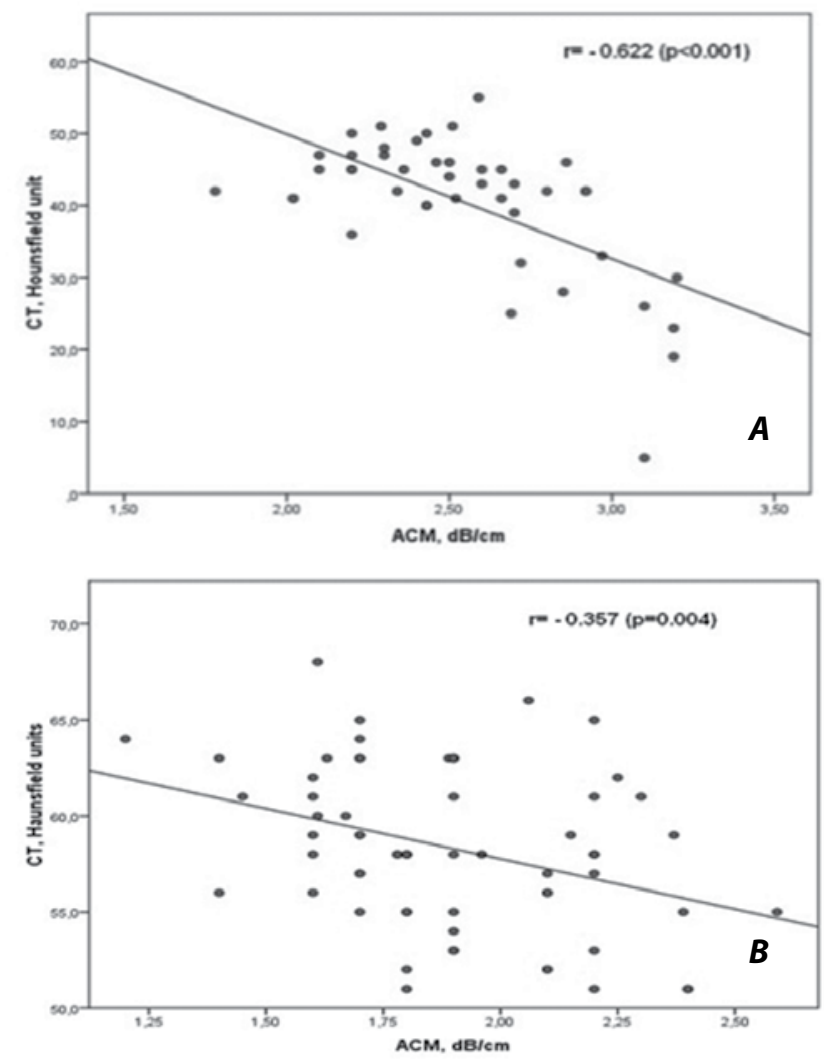

Fig. 1. Correlation of the ACM and CT data (stiffness of liver parenchyma) in patients with fatty liver ( $A$ ) and in controls (B); $r$-Pearson coefficient.

steatosis evaluation was $0,925(95 \% \mathrm{Cl} 0.877-0,973)$. Cutoff value was $>2.27 \mathrm{~dB} / \mathrm{cm}$ with sensitivity $91.5 \%$, specificity $77.3 \%$, positive prognostic value $84.6 \%$ and negative prognostic value $83.8 \%(p<0.001)$ (Table 1; Fig. 2).

Table 1

Diagnostic value of ACM for diagnosis of liver steatosis using CT as a reference method

\begin{tabular}{ll}
\hline Parameters & NAFLD vs. Control \\
\hline Cut-off point, dB/cm & $>\mathbf{2 . 2 7}$ \\
Sensitivity, \% & 77.3 \\
Specificity, \% & 91.5 \\
NPV, \% & 83.8 \\
PPV, $\%$ & 84.6 \\
AUROC & $\mathbf{0 . 9 2 5}$ \\
$95 \%$ CI & $\mathbf{0 . 8 7 7 - 0 . 9 7 3}$ \\
P (AUROC) & $<0.001$ \\
\hline reviations: $N P V-$ negative prognostic value, PPV-positive prognostic value,
\end{tabular}

AUROC-area under the ROC-curve, $95 \% C I-95 \%$ confidence interval for AUROC.

Abbreviations: NPV - negative prognostic value, PPV positive prognostic value, $A U R O C$ - area under the ROC-curve, 95\% Cl - 95\% confidence interval for AUROC. 


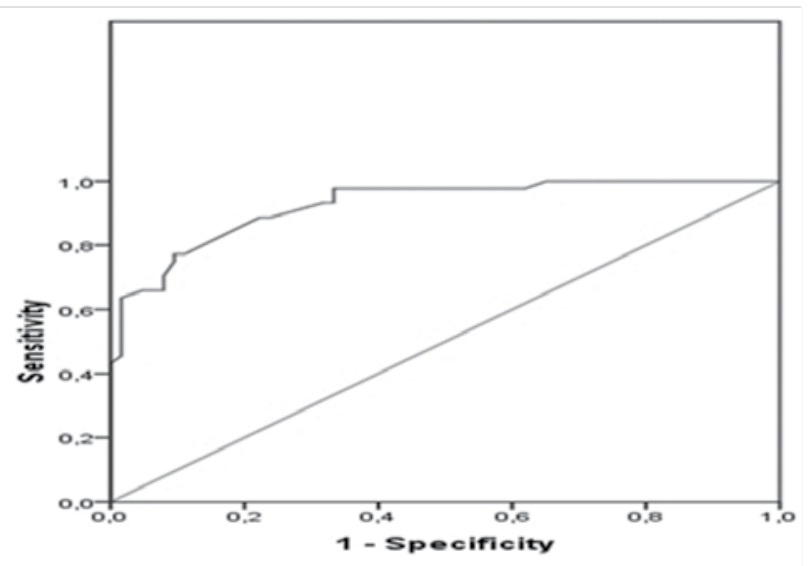

Fig. 2. Diagram of sensitivity and specificity of ACM for diagnosis of liver steatosis ( $77.3 \%$ and $91.5 \%$ respectively) according to CT data.

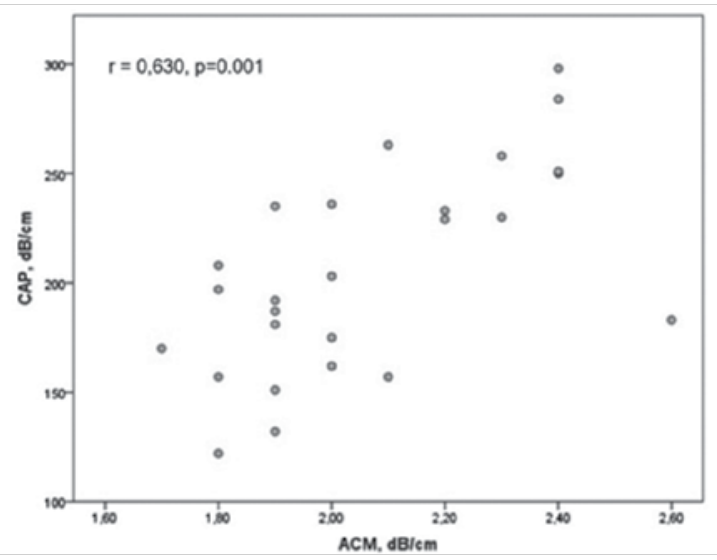

Fig. 3. Correlation of ACM with CAP (performed on Fibroscan); $r$-Pearson coefficient.

Comparing ACM and CAP on Fibroscan (Echosens, France) in 49 patients with fatty liver the positive medium correlation was found $(r=0.630, p<0.001)$ (Fig. 3).

The age of patients with T2DM and NAFLD was $57.75 \pm 8.62$ years; duration of T2DM 10.19 \pm 5.99 years, maximum value of steatosis $2.6 \pm 0.31 \mathrm{~dB} / \mathrm{cm}$, maximum value of right lobe elastography $6.7 \pm 1.47$ $\mathrm{kPa}$, maximum value of left lobe elastography $6.5 \pm 1.42$ $\mathrm{kPa}$, hepatorenal index $1.55 \pm 0.36$, size of right lobe $161.8 \pm 16.36 \mathrm{~mm}$, size of left lobe $72.95 \pm 12.53 \mathrm{~mm}$, diameter of vena porta $11.73 \pm 1.31 \mathrm{~mm}$, maximum blood flow velocity of portal vein $25.49 \pm 5.07 \mathrm{~cm} / \mathrm{sec}$. In B-mode the biometry and assessment of echotexture of such organs of abdominal cavity as liver, gall bladder, pancreas and lymph nodes were conducted. NAFLD was diagnosed according to the Hamaguchi criteria. 99 patients (91.4\%) matched these criteria. Right lobe was enlarged in 104 patients (99\%) and in 31 patients $(29.5 \%)$ the size of left lobe was normal. Chronic pancreatitis was diagnosed in 104 patients (99\%). In all patients with T2DM and NAFLD US-steatography (-metry) with evaluation of ACM in the right lobe was performed and the grades of steatosis (in $\mathrm{dB} / \mathrm{cm}$ ) were following:

1. S0 - 9 patients $(8.6 \%)$

2. S1 - 4 patients $(3.8 \%)$

3. 52 - 73 patients $(69.5 \%)$

4. S3 - 19 patients (18.1\%)

Shear wave elastography and fibroelastometry/shear wave elastometry of the right liver lobe was performed for evaluation of fibrosis stage and cirrhosis with Metavir scale [3] in kPa:

1. F0 (no fibrosis): 30 patients (29.7\%)

2. F1 (mild fibrosis): 35 patients (34.7\%)

3. F2 (moderate fibrosis): 30 patients (29.7\%)

4. F3 (severe fibrosis): 5 patients (5\%)

5. F4 (cirrhosis): 1 patient (1\%)

Left liver lobe was investigated for evaluation of fibrosis stage and cirrhosis with Metavir scale in $\mathrm{kPa}$ [3]:

1. F0 (no fibrosis): 32 patients (34\%)

2. F1 (mild fibrosis): 38 patients (40\%)

3. F2 (moderate fibrosis): 20 patients (21\%)

4. F3 (severe fibrosis): 4 patients $(4.2 \%)$

5.F4 (cirrhosis): 1 patient (1.1\%)

In 10 patients shear wave elastography of left liver lobe wasn't performed because of high position of the liver and intestinal gas.

Evaluation of MPE in diagnosis of NAFLD in patients with T2DM is based on complex of US methods such as B-mode, dopplerography and dopplerometry, strain and shear wave elastography, elastometry, ACM, hepatorenal index on the US Soneus P7 (Ultrasign, Ukraine) device with convex transducer 1-6 MHz in the right liver lobe. Correlation analysis of the data of patients with T2DM was made. The following parameters such as maximum value of right liver lobe elastography $(\mathrm{kPa})$, maximum value of left liver lobe elastography $(\mathrm{kPa})$, medium value of hepatorenal index, size of right lobe $(\mathrm{mm})$ and size of left lobe $(\mathrm{mm})$ were evaluated.

There was found positive medium correlation of maximum value of steatosis (ACM) with hepatorenal index (Fig. 4), size of right liver lobe (Fig. 5) and size of left liver lobe (Fig. 6).

\section{DISCUSSION}

The ACM is a new US method for quantitative evaluation of liver steatosis in real time which was proved in our study with statistically significant correlation of ACM with the CT data as a reference method and in ROC-analyses. 


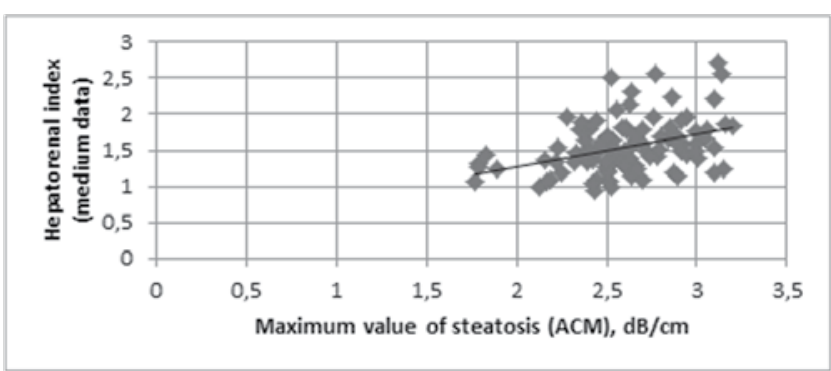

Fig. 4. Correlation of maximum value of steatosis with hepatorenal index $(r=0.4 ; p<0.001)$.

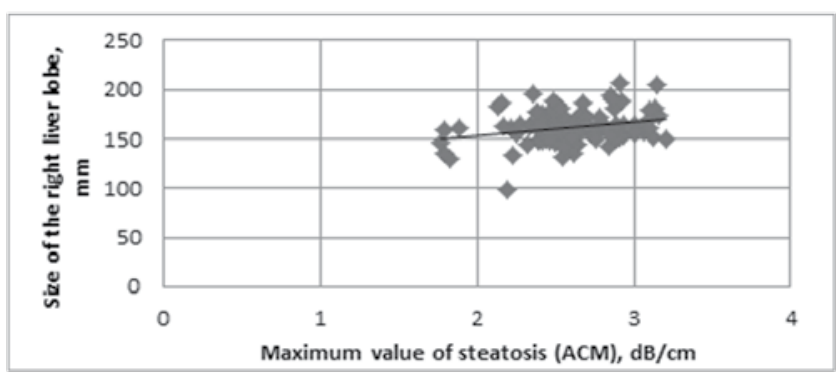

Fig. 5. Correlation of maximum value of steatosis with the size of right lobe $(r=0.3 ; p=0.008)$.

It is known that in many countries the methodology of CAP and transient elastography on the Fibroscan (Echosens, France) device are used as noninvasive methods for evaluation of steatosis and liver stiffness measurement $[3,8,10]$. Performing of step by step algorithm of MPE in real time includes comprehensive investigation of abdominal cavity in B-mode, evaluation of the stage of steatosis quantitatively, performing of liver stiffness measurement, hepatorenal index, dopplerography and dopplerometry on the Soneus P7 (Ultrasign, Ukraine) device with convex transducer 1-6 MHz simultaneously and all these methods are economically affordable. Shear wave elastography and elastometry is performed with the help of navigation which increases diagnostic accuracy [11]. Methodology of shear wave elastography and elastometry is not limited by subcutaneous abdominal fat and ascites because US shear wave is formed in the region of investigation directly [2]. SM is characterized by the same principle. That's why MPE meets all the requirements of modern noninvasive diagnosis of NAFLD for evaluation of stages of steatosis and fibrosis according to EASL Guidelines (2016). It is known that steatosis is performed by fat accumulation in the liver which leads to the enhancement of its size. In our investigation there was revealed statistically significant correlation of maximum value of steatosis with hepatorenal index, size of right and left liver lobes which proves the evaluation of lipids in liver with the

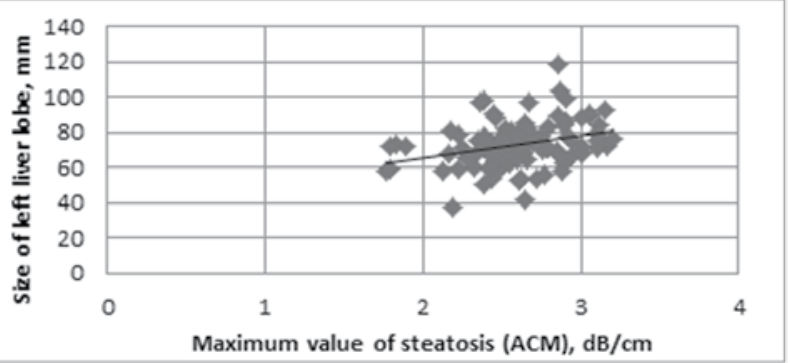

Fig. 6. Correlation of maximum value of steatosis with the size of the left liver lobe $(r=0.3 ; p=0.001)$.

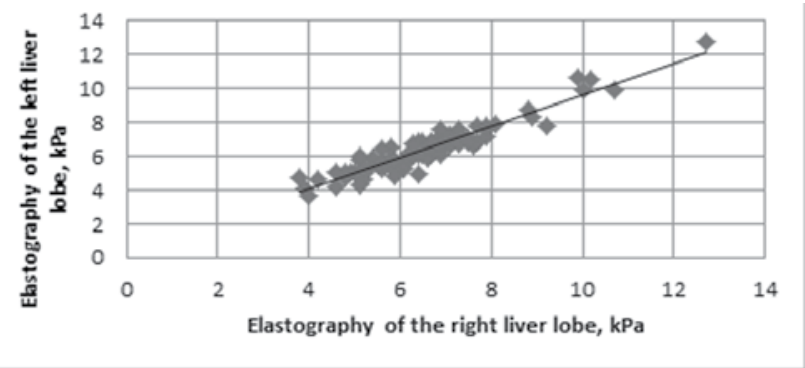

Fig. 7. Correlation of maximum value of the left liver lobe elastography with the maximum value of the right liver lobe elastography $(r=0.95 ; p<0.001)$.

ACM and diagnostic value of this method. According to the literature influence of steatosis on fibrosis and relations of these processes are being studied [13, 15]. The degrees of NAFLD include steatosis and steatohepatitis (early steatohepatitis with no or mild fibrosis; fibrotic steatohepatitis) [7]. In our investigation there was not found correlation of maximum value of steatosis with the data of elastography, diameter and maximum blood flow velocity of portal vein, that's why steatosis and impaired liver stiffness may be different pathological processes in patients with T2DM including different impact factors. Methodology of shear wave elastography represents the condition of liver stiffness [9] that was confirmed by the presence of statistically significant correlation of the data of right and left liver lobes elastography. Steatosis leads to the impaired blood flow of the liver [16]. That's why MPE is a comprehensive method of simultaneous diagnosis and evaluation of the NAFLD, liver stiffness measurement, impaired hemodynamics for following patients with T2DM up.

\section{CONCLUSIONS}

1. In this investigation there was proved the diagnostic accuracy of ACM as a quantitative method of steatosis assessment in real time.

2. There was also proved performing of MPE as the comprehensive method for simultaneous diagnosis and evaluation of the NAFLD, quantitative assessment 
of the stage of fatty liver, liver stiffness measurement and impaired hemodynamics for following patients with T2DM up.

Financial support. This investigation wasn't supported by any special grants by public, commercial and non-profit organizations.

Conflict of interest. The authors who have taken part in this study declared that they do not have anything to disclose or conflict of interest with respect to this manuscript.

Authors' contributions. Bodnar P. made the plan of the research. Marunchyn N. recruited patients for the research, worked with the data and made statistical analysis. Dynnyk O. invented the ACM and implemented the MPE. Gurianov V. consulted about the statistical analysis and presentation of the data.

Acknowledgements. We thank the doctors of Kyiv Clinical Endocrinological Centre and the Department of Endocrinology of Bogomolets National Medical University.

\section{ЛITEPATУРA REFERENCES}

1. Atlas IDF 2015 [Internet]. Available from: http:// www.diabetesatlas.org/resources/2015-atlas.html.

2. Bodnar PM, Dynnyk OB, Mykhalchyshyn HP, et al. Otsinka diahnostychnoi efektyvnosti elastohrafii khvyli zsuvu u khvorykh na tsukrovyi diabet 2 typu z nealkoholnym steatohepatozom. Endokrynolohiia. 2012;17(3):39-48. [Ukrainian].

3. Castera L, Forns $X$, Alberti A. Non-invasive evaluation of liver fibrosis using transient elastography. J Hepatol. 2008;48:835-847.

4. Chauhan $A$, Sultan $R L$, Furth $L$, et al. Diagnostic accuracy of hepatorenal index in the detection and grading of hepatic steatosis. J Clin Ultrasound. 2016;44(9):580-586.

5. Dynnik OB, Fedusenko AA, Kobylyak NN, Linskaya AV. 6 izmereniy ultrazvukovoy diagnostiki diffuznykh zabolevanyiy pecheni. Promeneva diahnostyka, promeneva terapiia. 2016;3-4:69-84. [Russian].

6. Dynnyk O, Fedusenko O, Kobyliak N. Multi-parametric ultrasound ( $\mathrm{mp}$-US) paradigm in the chronic diffuse liver disease diagnosis. Abstract session. XXIV Annual Meeting of the Latin American Association for the Study of the Liver. Annals of Hepatology. 2016;15(6):953-982.

7. EASL-EASD-EASO Clinical Practice Guidelines for the management of non-alcoholic fatty liver disease. J Hepatol. 2016;64:1388-1402.
8. Bamber J, Cosqrove $D$, Dietrich $C F$, et al. EFSUMB guidelines and recommendations on the clinical use of ultrasound elastography. Part 1: Basic principles and technology. Ultraschall Med. 2013;34(2):169184.

9. European Association for the Study of the Liver, Asociacion Latinoamericana para el Estudio del Higado. EASL-ALEH Clinical Practice Guidelines: non-invasive tests for evaluation of liver disease severity and prognosis. J Hepatol. 2015;63:237-264.

10.Ferraioli G, Filice C, Castera L, et al. WFUMB guidelines and recommendations for clinical use of ultrasound elastography: Part 3: liver. Ultrasound Med Biol. 2015 May;41(5):1161-1179.

11. Hamaguchi $M$, Kojima $T$, Itoh $Y$, et al. The severity of ultrasonographic findings in nonalcoholic fatty liver disease reflects the metabolic syndrome and visceral fat. Am J Gastroenterol. 2007 Dec;102(12):27082715.

12. Myers RP, Pollett $A$, Kirsch $R$, et al. Controlled Attenuation Parameter (CAP): a noninvasive method for the detection of hepatic steatosis based on transient elastography. Liver International. 2012;32(6):902-910.

13.Petta S, Vanni E, Bugianesi E, et al. The combination of liver stiffness measurement and NAFLD fibrosis score improves the noninvasive diagnostic accuracy for severe liver fibrosis in patients with nonalcoholic fatty liver disease. Liver International. 2015;35(5):1566-1573.

14.SassoM, Tengher-Barnal,ZiolM, etal. Novel controlled attenuation parameter for noninvasive assessment of steatosis using Fibroscan $\left({ }^{\circledR}\right)$ : validation in chronic hepatitis C. J Viral Hepat. 2012 Apr;19(4):244-253.

15.Singh S, Allen AM, Wang Z, et al. Fibrosis progression in nonalcoholic fatty liver vs nonalcoholic steatohepatitis: a systematic review and metaanalysis of paired-biopsy studies. Clin Gastroenterol Hepatol. 2015 Apr;13(4):643-654.

16.Stern C, Castera L. Noninvasive diagnosis of hepatic steatosis. Hepatol Int. 2017;11(1):70-78.

\section{PEЗЮME}

Оценка мультипараметрической эхографии в диагностике неалкогольной жировой болезни печени при сахарном диабете 2 типа Н.А. Марунчин, П.Н. Боднар, О.Б. Дынник, В.Г. Гурьянов

Введение. В связи со значительным распространением сахарного диабета 2 типа (СД2) 
и неалкогольной жировой болезни печени (НАЖБП) должны быть разработаны новые неинвазивные методы количественного определения стеатоза и всесторонней оценки течения НАЖБП.

Цель исследования - оценить возможности мультипараметрической эхографии (МПЭ) в диагностике НАЖБП у пациентов с СД2.

Материалы и методы. МПЭ представляет собой пошаговый, одномоментный алгоритм исследования органов брюшной полости в В-режиме, количественной оценки стадии жирового гепатоза с помощью измерения коэффициента угасания (ИКУ), определение жесткости паренхимы печени методами сдвиговолновой эластографии и фиброэластометрии, расчет гепаторенального индекса, проведение допплерографии и допплерометрии на аппарате Soneus P7 (Ultrasign, Украина) с конвексным датчиком 1-6 МГц. Диагностическая точность ИКУ как одного из методов МПЭ была оценена у 142 пациентов. Компьютерная томография (КТ) была представлена как референтный метод. МПЭ была проведена у 105 пациентов с СД2.

Результаты и обсуждение. В исследовании была определена статистически значимая связь ИКУ с данными КТ у пациентов с жировой болезнью печени и в контрольной группе. Также была определена связь ИКУ с показателями параметра контролируемого угасания (САР). У пациентов с СД2 при проведении МПЭ была выявлена связь максимального значения ИКУ с гепаторенальным индексом, размерами правой и левой долей печени. Кроме этого, была определена связь максимального значения показателей эластографии правой доли печени с максимальным значением эластографии левой доли печени.

Выводы. В исследовании была доказана диагностическая точность ИКУ как количественного метода определения стеатоза печени в режиме реального времени. Также показана ценность МПЭ как метода одновременной диагностики и всесторонней оценки НАЖБП, количественного определения степени жирового гепатоза, жесткости паренхимы печени и нарушения гемодинамики с целью оптимизации ведения пациентов с СД2.

Ключевые слова: сахарный диабет 2 типа, неалкогольная жировая болезнь печени, эластография, стеатометрия, ультразвуковая диагностика, мультипараметрическая эхография.

\section{PEЗЮME}

Оцінка мультипараметричної ехографії у діагностиці неалкогольної жирової хвороби печінки при цукровому діабеті 2 типу Н.А. Марунчин, П.М. Боднар, О.Б. Динник, В.Г. Гур'янов

Вступ. Узв'язку зі значним поширенням цукрового діабету 2 типу (ЦД2) і неалкогольної жирової хвороби печінки (НАЖХП) необхідно розробити нові неінвазивні методи кількісного визначення стеатозу і всебічної оцінки перебігу НАЖХП.

Мета дослідження - оцінити можливості мультипараметричної эхографії (МПЕ) у діагностиці НАЖХП у пацієнтів із ЦД2.

Матеріали і методи. МПЕ являє собою покроковий, одномоментний алгоритм обстеження органів черевної порожнини у В-режимі, кількісної оцінки стадії жирового гепатозу за допомогою вимірювання коефіцієнту згасання (ВКЗ), визначення жорсткості паренхіми печінки методами зсувнохвильової еластографії і фіброеластометрії, розрахунок гепаторенального індексу, проведення доплерографії и доплерометрії на приладі Soneus P7 (Ultrasign, Україна) з конвексним датчиком 1-6 МГц. Діагностична точність ВКЗ як одного із методів МПЕ була оцінена у 142 пацієнтів. Комп'ютерна томографія (КТ) була представлена як референтний метод. МПЕ була проведена у 105 пацієнтів з ЦД2.

Результати і обговорення. У дослідженні було визначено статистично значущий зв'язок ВКЗ 3 даними КТ у пацієнтів із жировою хворобою печінки і у контрольній групі. Також було визначено зв'язок ВК3 із показниками параметру контрольованого згасання (САР). У пацієнтів із ЦД2 при проведенні МПЕ було виявлено зв'язок максимального значення ВK3 із гепаторенальним індексом, розмірами правої і лівої часток печінки. Окрім цього, було виявлено зв'язок максимального значення показників еластографії правої частки печінки з максимальним значенням еластографії лівої частки печінки.

Висновки. У дослідженні доведено діагностичну точність ВКЗ як кількісного методу визначення стеатозу печінки у режимі реального часу. Також показана цінність МПЕ як методу одночасної діагностики і всебічної оцінки НАЖХП, кількісного визначення ступеню жирового гепатозу, жорсткості паренхіми печінки і порушення гемодинаміки 3 метою оптимізації ведення пацієнтів із ЦД2.

Ключові слова: цукровий діабет 2 типу, неалкогольна жирова хвороба печінки, 
еластографія, стеатометрія, ультразвукова діагностика, мультипараметрична ехографія.

\section{SUMMARY}

Evaluation of multiparametric echography in diagnosis of nonalcoholic fatty liver disease in type 2 diabetes mellitus

Marunchyn N, Bodnar P, Dynnyk O, Gurianov V

Background. New noninvasive methods for quantitative evaluation and comprehensive investigation of liver steatosis must be developed because of prevalence of type 2 diabetes mellitus (T2DM) and nonalcoholic fatty liver disease (NAFLD).

The aim of this study is evaluation of multiparametric echography (MPE) in diagnosis of NAFLD in patients with T2DM.

Materials and methods. MPE includes step by step simultaneous algorithm of investigation of organs of abdominal cavity in B-mode, quantitative evaluation of stage of hepatic steatosis with attenuation coefficient measurement (ACM), liver stiffness measurement with shear wave elastography and fibroelastometry, hepatorenal index, dopplerography and dopplerometry on Soneus P7 device (Ultrasign, Ukraine) with convex transducer 1-6 MHz. Diagnostic accuracy of ACM as a part of MPE was assessed in 142 patients and CT was used as a reference method. MPE was performed in 105 patients with T2DM.
Results. There was revealed significant correlation of ACM with the data of CT in patients with fatty liver disease and in control group. The ACM also correlated with CAP significantly. In patients with T2DM MPE revealed the correlation of maximum value of ACM with hepatorenal index, size of right liver lobe and size of left liver lobe. Besides there was found correlation of the maximum value of the right liver lobe elastography with the maximum value of the left liver lobe elastography.

Conclusions. In this investigation there was proved the diagnostic accuracy of ACM as a quantitative method of liver steatosis assessment in real time. There was also shown the value of MPE as the comprehensive method for simultaneous diagnosis and evaluation of the NAFLD, quantitative assessment of the stage of fatty liver, liver stiffness measurement, impaired hemodynamics for optimization of following patients with T2DM up.

Key words: type 2 diabetes mellitus, nonalcoholic fatty liver disease, elastography, steatometry, ultrasound diagnostics, multiparametric echography.

Дата надходження до редакиії 08.04.2017 p. 